\title{
Mazierska, Ewa and Zsolt Győri, ed. 2019. Popular Music and the Moving Image in Eastern Europe. New York: Bloomsbury Academic. 250 pp.
}

\section{Reviewed by Lilla Tőke, City University of New York}

Popular music in Socialist and Post-socialist Eastern Europe was one of the important cultural spheres where ideological and political dissent could be embraced by millions of young people. Before 1989 underground rock music, blues, and other Western music genres were largely disseminated through underground channels. At the same time, local bands also developed their own versions of these genres by adapting them to the specific musical and political traditions in the region. Besides the dissemination of Western styles, folk music and folk dance movements also served as crucial tools for political resistance.

Starting in the early 1990s, new music genres found their way into Eastern Europe and since then local music industries have continued to play a key role in the region's cultural arena. The political nature of Eastern European music is the focus of several monographs and collections such as Rocking The State: Rock Music And Politics In Eastern Europe And Russia by Sabrina Petra Ramet (1994), Performing Pain: Music and Trauma in Eastern Europe by Maria Cizmic (2012), and Youth and Rock in the Soviet Bloc: Youth Cultures, Music, and the State in Russia and Eastern Europe by William Jay Risch (2015). However, the intersection between music and cinema has so far been largely overlooked, if not altogether neglected. The articles in the volume Popular Music and the Moving Image in Eastern Europe, edited by Ewa Mazierska and Zsolt Győri, offer a long overdue correction to this imbalance.

The present collection is a testimony to both Eastern Europeans' long-standing fascination with British and American music and to the ways in which this music has continuously been appropriated and infused with an Eastern European "flair." Exactly what the word "flare" means is the subject of the studies carefully curated by Ewa Mazierska and Zsolt Györi. The editors describe three identifiable themes in the collection. The first group of studies examines Eastern European musicals or "films approximating to this genre" (18). The second part of the book deals with films that "document specific music or music traditions" (19). Short experimental films are at the center of the book's third and last part. Interestingly, neither the Table of Contents nor the book's layout show any indication of these distinct parts. Rather, the articles represent an eclectic, playful mix of topics and issues that sometime intersect and sometime switch quite abruptly. Predictably, about half of the articles examine films that utilize rock music of the 1960s to offer cultural and political critique or else a sense of nostalgia. This

\footnotetext{
*ltoke@lagcc.cuny.edu
}

$($ (c) $)$ EY 
Töke, Lilla. "Mazierska, Ewa and Zsolt Győri, ed. 2019. Popular Music and the Moving Image in Eastern Europe. New York: Bloomsbury Academic. 250 pp." Hungarian Cultural Studies. e-Journal of the American Hungarian Educators Association, Volume 13 (2020) DOI: 10.5195/ahea.2020.413

scholarly paradigm, which examines popular culture as a tool for ideological dissent, is quite common in Eastern European studies. However, several authors surprise us by exploring original subjects, such as music videos, music documentaries, and unique music genres from the pre- and post-Socialist Eastern Europe.

Evan Torner's opening article, “1968 Leftist Utopianism in Young Girls of Rochefort and Hot Summer" looks at the ways in which music and film work together to create a utopian social collective. Musicals, he argues, offer "a possibility to create a world in which men and women would be free to explore their individual creativity and desires without being held back by socioeconomic and political limitations" (41); in other words, musicals offer us a utopian escape. Gabriella Filippi's discussion likewise focuses on musicals, and she examines Romanian socialist musicals chronologically. On the one hand, she effectively shows that socialist musicals are "markedly different from their Hollywood counterparts" (60). On the other hand, examining women's roles in these films, Filippi demonstrates that socialist musicals failed to propagate the message of social progress and modernism in socialist Romania due to the rather conservative world they presented with regard to women's roles. The last article on this topic was written by Balázs Varga and it examines Hungarian post-socialist musicals that recreate a memory of socialism in the country. In "Worlds That Never Were: Contemporary Eastern European Musical Comedies and the Memory of Socialism," Varga claims to focus on "contemporary" musicals. While it is important to note that all films are from the 1990s and early 2000s, his argument that none of the films he examines "portray the past with uncritical nostalgia" (78) brings a refreshing voice into discussions about socialism and nostalgia.

Hajnal Király's “Pop Music, Nostalgia and Melancholia in Dollybirds and Liza, the Fox Fairy" also examines the ways in which cinematic music evokes nostalgia and melancholia. She makes the claim that film and music can serve as "coping mechanisms in periods of social and economic insecurity that follow political changes" (84). Dollybirds helps an older generation embrace their nostalgia for the 1950s and 1960s while dealing with a drastically new post-1989 reality. At the same time, in her view, Liza, the Fox Fairy responds to the melancholic longing of younger generations for a time and space away from present-day capitalist consumer societies. The next study, by Jonathan Owen, shifts the focus from musicals to Czech New Wave cinema and pop music as it explores the relationship among film, music, and political critique in the 1960s. His article, "When the Golden Kids Met the Bright Young Men and Women," makes the case that the celebration of popular music is an integral part of the "lighthearted, formally adventurous and implicitly politically and socially critical" (114) Czech New Wave cinema.

Rock music continued to play a key role in the popular cultures of Eastern Europe through the 1970s and 1980s. During this time period, underground rock music in particular was essential to constructing ideological dissent through "existential aimlessness and an all-pervasive sense of loss" (121). According to the article written by Zsolt Györi, experimental cinema and newly emerging rock videos shared a "new [political] sensitivity" (120), meaning a cultural critique of utopian socialism. Yugoslvia and Poland, we find out from the following two articles, had robust disco cultures in the 1970s and 1980, a new genre that found its way into a multitude of film and television productions. Marko Zubak's "Socialist Night Fever: Yugoslav Disco and Television" offers the readers a comprehensive historical and cultural overview of disco music. The author argues that the function of disco was "ambivalent" and "eclectic" (152) in ways that go beyond simple dichotomies such as "oppression" versus "dissent." Ewa Marziewska's study compares the robust Polish disco polo and techno music cultures as they are portrayed in two documentary films directed by Maria Zmarz-Koczanowicz. She outlines why these two music 
Töke, Lilla. "Mazierska, Ewa and Zsolt Győri, ed. 2019. Popular Music and the Moving Image in Eastern Europe. New York: Bloomsbury Academic. 250 pp." Hungarian Cultural Studies. e-Journal of the American Hungarian Educators Association, Volume 13 (2020) DOI: 10.5195/ahea.2020.413

genres (popular in the 1990s and early 2000s respectively) can be seen as "contrasting" (167). Zmarz-Koczanowicz's films, in her view, represent disco polo as utilitarian, politically-engaged and related to "low," popular culture while they depict techno as "politically neutral, urban and cosmopolitan" (167).

In the end, the book returns to the topic of music in communist Eastern Europe and its power to undermine aesthetic, social and political norms. Andrej Šprah's study focuses on Slovenian cinema, specifically the alternative, experimental cinema of director Karpo Godina, from the 1960s and 1970s. He explores the ways in which music serves as a catalyst to intensify the subversive potential of these films. Ewa Marzieska's second article in the collection, "Polish Music Videos: Between Parochialism and Universalism," returns to the topic of music videos. Mazierska argues that disco polo and electronic music videos in Poland disclose a cultural tension between a more inward looking, national(ist) approach and a more universalist, international approach that connects Polish music with Western genres. Pop-folk music has been a widely popular genre in both socialist and post-socialist Eastern Europe and in the next article, Maya Nedyalkova examines pop-folk music videos that mix Bulgarian and Western visual and narrative symbols "to create new models of cultural identification and value" (206). The last article in the collection also addresses the subject of music videos. Anna Bátori's analysis, "Postsocialist Social Reality in Hungarian Rap Music Videos" focuses on rap music as adapted to the post-socialist Eastern European reality. She shows that Hungarian rap is unique in its ability to represent a space between past and present in a way that offers a powerful critique of modern, capitalist culture.

On the whole, Popular Music and the Moving Image in Eastern Europe is a highly eclectic snapshot of the work that needs to be done around the intersections of Eastern European music and visual culture. From cinema to television and video, the book covers a surprising variety of topics, many different genres in music and film that stretch over a decades-long time period. The articles sometimes complement one another, sometimes overlap as they create a productive scholarly dialogue with one another. A pioneering attempt to better understand how Eastern European music and film are interrelated, this collection offers interesting and provocative insights to veteran scholars of Eastern European culture, and it can also be informative to emerging students of music and film. 